\title{
Microbiological quality of different dried insects sold at Thohoyandou open market, South Africa
}

\author{
Ramashia, S.E., Tangulani, T., *Mashau, M.E. and Nethathe, B. \\ Department of Food Science and Technology, School of Agriculture, University of Venda, Private Bag \\ X5050, Thohoyandou, 0950, Limpopo Province, South Africa
}

\author{
Article history: \\ Received: 15 May 2020 \\ Received in revised form: 26 \\ June 2020 \\ Accepted: 4 July 2020 \\ Available Online: 23 August \\ 2020
}

Keywords:

Mopane worms,

Termites,

Stink bugs,

Food hygiene and safety,

Microbiological analyses

DOI:

https://doi.org/10.26656/fr.2017.4(6).233

\section{Introduction}

An estimated two billion people, mostly from underdeveloped countries in Africa, Asia and South America, harvest more than 2000 different species of edible insects for human consumption (van Huis, 2013; Hamerman, 2016; Kooh et al., 2019). Insects are a rich source of protein, fats, micronutrients (copper, iron, selenium, zinc) and B-group vitamins $\left(\mathrm{B}_{2}, \mathrm{~B}_{5}, \mathrm{~B}_{9}\right)$ (Kouřimská and Adámková, 2016; Osimani et al., 2016). The most consumed insects are beetles, caterpillars, bees, wasps and ants (14\%), mopane worms, locusts, crickets, leafhoppers, planthoppers, scale insects, true bugs, termites, dragonflies and flies (Osimani et al., 2016; Pal and Karmakar, 2018). Generally, insects are consumed both as the main dishes or simply eaten as a snack after they have been fried or sun-dried (Figueiredo et al., 2015; Musundire et al., 2016).

Traditionally, insects are exposed to the soil during sun-drying where they are easily contaminated and this additionally compounded by poor storage conditions
(Klunder et al., 2012). Sun-drying has been used from the age of as early as 20000 BC (Bourdoux et al., 2016). This indicates that drying is one of the oldest methods used to preserve foods. It reduces water which improves the quality by reducing water activity, increases the shelf -life of dried foods and helps to reduce the microbial growth on dried foods. It is cheap, simple and inexpensive to practice. However, it has disadvantages of contamination due to insects, birds, rodents and other environmental factors which have negative effects on public health (Farahbakhsh et al., 2015).

Fresh insects contain high bacterial load (Enterobacteriaceae and bacterial spores) as compared to dried insects. There is no specific criterion on how to package insects as most of them are stored in containers and are therefore easily exposed to various microorganisms as compared to other fresh and finished products (Amadi and Kiin-Kabari, 2016). Street vendors weigh the insects using a cup and put them inside a plastic (Oppong, 2013). These insects are exposed to the sun, dust and poor handling procedures (Cloutier, 2015). 
Poor packaging and storage may also contribute to microbial contamination (Raphael et al., 2014). Foods from animal origin are generally infected by food-borne infectious diseases which account more than $50 \%$ of all diseases in the globe (Kooh et al., 2019). Insects are commonly harvested from natural environments and there is a great concern about the hygiene and food safety around the world due to the way they are handled and stored (Messina et al., 2019). In addition, insects are rich in nutrients and moisture and this may cause high microbial growth (Klunder et al., 2012). Therefore, different hygiene measures when it comes to insects as a source of food should be implemented to reduce microbial populations. These measures involve various processing steps such as heating, freezing, drying and frying, boiling, grinding, packaging and storage of the final products which would be ready for consumption (Medigo et al., 2017; Kooh et al., 2019).

Insects are associated with high microbial growth of pathogenic, commensal and spoilage fungi due to poor processing and storage conditions along the value chain (Mujuru et al., 2014; Osimani et al., 2016; Schluter et al., 2017). Microbiological or hygiene indicators that are used to give information on the microbial loads of foods are total plate count, lactic acid bacteria (LAB) and Enterobacteriaceae (Kooh et al., 2019). Most of the microorganisms that have been isolated from insects include Enterobacteriaceae, Staphylococcus aureus, Bacillus cereus, Listeria monocytogenes, Salmonella spp. Clostridium perfringens, C. botulinum and LAB (Amadi and Kiin-Kabari, 2016; van der Fels-Klerx et al., 2018). Other isolated species include Escherichia coli (Park et al., 2019), Enterobacter sakazakii, Pseudomonas aeruginosa and Yersinia species (Kooh et al., 2019).

Milanovic et al. (2016) studied microbial analysis of eleven species of marketed edible insects such as small crickets, locusts, black ants, winged termite alates, rhino beetles, mole crickets and black scorpions. However, there is little information available on the microbial analysis of dried insects and personal hygiene of the street vendors. Therefore, this study investigated the microbial analyses of dried insects (mopane worms, termites and stink bug) sold at Thohoyandou open market, Limpopo Province, South Africa.

\section{Materials and methods}

\subsection{Food hygiene practices}

A checklist adopted from Muinde and Kuria (2005) and Samapundo et al. (2015) was used to assess food hygiene practices of all fifteen street vendors selling dried insects. The food hygienic practices were assessed and then expressed in percentages.

\subsection{Study area and sampling procedure}

A total of 45 dried insects (Figure 1) such as mopane worms (15), termites (15) and stink bug (15) were randomly purchased from five different street-vendors in Thohoyandou, South Africa. They were packaged in polystyrene plastics, stored in a cooler box and transported to the laboratory for microbiological analysis and this was done in triplicates $(n=3)$. Medium and other chemicals were purchased from Lasec, Midrand, South Africa and all were Oxoid grades.

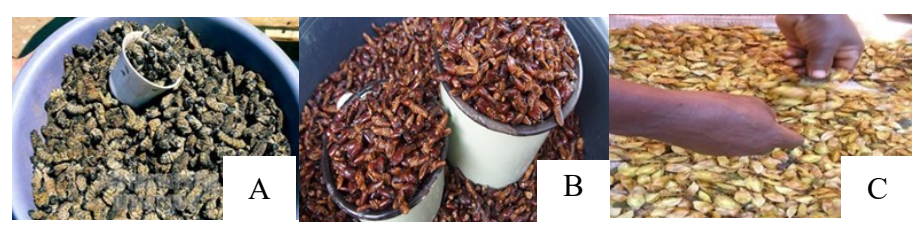

Figure 1. Dried insects sold in Thohoyandou open market, South Africa. (A) Mopane worms (B) termites and (C) stink bugs.

\subsection{Microbiological analyses of dried insects}

The dried insect samples were determined for coliforms, E. coli, Salmonella spp., S. aureus, total viable count and yeast and mould using the pour plate count method. For each dried insect sample, $10 \mathrm{~g}$ was weighed and homogenised with $90 \mathrm{~mL}$ buffered peptone water and serial dilutions were prepared up to $10^{-5}$ and the dilution was used for plating purpose. The plates were labelled properly based on the different media used; chromo select agar (CSA) for coliforms and E. coli, Xylose Lysine Desoxycholate agar (XLDA) for Salmonella spp., Baird Parker agar (BPA) for S. aureus, plate count agar (PCA) for total viable count and potato dextrose agar (PDA) for yeast and moulds. The plates were then incubated appropriately to allow the growth of microorganisms: CSA and XLDA at $37^{\circ} \mathrm{C}$ for $24 \mathrm{hrs}$, BPA and PCA at $37^{\circ} \mathrm{C}$ for $48 \mathrm{hrs}$ and $25^{\circ} \mathrm{C}$ for $72 \mathrm{hrs}$. Counts of bacteria, yeasts and moulds were made on the respective media (Mafune et al., 2016; Terentjeva et al., 2017; Omemu et al., 2018). For each dried insects samples, three measurements were taken. The plates were counted using colony counter for each microorganism. The counts were expressed as colony forming units per gram CFU/g (Ahmed et al., 2020).

\subsection{Data analysis}

All the experiments were conducted in triplicates and the averages of plate counts from three replications were converted to $\log _{10} \mathrm{CFU} / \mathrm{g}$. The data were subjected to analysis of variance using SPSS version 24 (SPSS, IBM, Chicago USA) and means were separated using the Duncan multiple range test. Significance was accepted at 
95\% confidence interval $(p<0.05)$ (Jeong-Eun et al., 2019).

\section{Results}

\subsection{Food hygiene practice}

Table 1 shows the hygiene practices of fifteen street vendors selling dried insects in Thohoyandou, South Africa. All fifteen street vendors were female and according to the observation during purchasing of insects, $66 \%$ of vendors were wearing appropriate clothes like aprons whereas 34\% were wearing their own clothes. In addition, few vendors (33\%) did not cover their hairs with hair nets or wrap them with any cloth. All respondents $(100 \%)$ sold dried insects from open containers. The street vendors used wooden tables or carts to put their bowls and $33 \%$ were clean and covered with table cloths. Most, $53 \%$ of the vendors, had proper shelter for selling site while $47 \%$ did not have proper shelter. In addition, all street vendors $(100 \%)$ were handling insects with hands. The street vendors did not have proper handwashing facilities (13\%) and $27 \%$ lacked waste disposable bin.

Table 1. Food safety and hygiene practices of street vendors selling dried insects $(\mathrm{n}=15)$

\begin{tabular}{lc}
\hline Hygiene practices & Yes (\%) \\
\hline Proper clothes & $10(66)$ \\
Hair covered not covered & $5(33)$ \\
Storage bowl clean & $7(47)$ \\
Storage bowl with insects not covered & $15(100)$ \\
Weighing cup not covered & $15(100)$ \\
Tables for putting bowl clean & $7(33)$ \\
Shelter for selling site available & $8(53)$ \\
Handling of insects with hands & $15(100)$ \\
Hand washing facilities available & $2(13)$ \\
Waste disposable bin & $4(27)$ \\
\hline
\end{tabular}

\subsection{Microbiological analysis of dried insects}

\subsubsection{Microbial analysis of mopane worms}

Table 2 shows the results of microbial analyses detected from mopane worm sample. Coliforms ranged from 0 to $1.9964 \pm 0.02 \log _{10} \mathrm{CFU} / \mathrm{g}$ for locations L1 to L5. The highest coliform count was obtained from location L2 whereas L3 to L5 had no count. E. coli was highest on L1 with $1.7071 \pm 0.02 \log _{10} \mathrm{CFU} / \mathrm{g}$ however, L3 to L5 had no count. Therefore, coliforms and E. coli were not detected on locations L3 to L5. Salmonella species had the highest count on location L2 with $1.5896 \pm 0.01 \log _{10} \mathrm{CFU} / \mathrm{g}$. The species were not detected on locations L1, L4 and L5. Staphylococcus aureus was not detected on locations L1 to L3 but had the highest count on L4 with $1.7707 \pm 0.00 \log _{10} \mathrm{CFU} / \mathrm{g}$. The highest total plate count was on L2 with $1.9422 \pm 0.02 \log _{10} \mathrm{CFU} /$ $\mathrm{g}$ and the lowest count on L4 with $1.2341 \pm 0.12 \log _{10}$ $\mathrm{CFU} / \mathrm{g}$. Yeast counts ranged from $1.9681 \pm 0.01$ to $1.6972 \pm 0.14 \log _{10} \mathrm{CFU} / \mathrm{g}$. The highest yeast count was obtained from L1 and the lowest count from L3. Mould counts ranged from 0 to $1.2594 \pm 0.24 \log _{10} \mathrm{CFU} / \mathrm{g}$ whereas the highest count was obtained from L1 and L2 had no mould count.

\subsubsection{Microbial analysis of termites}

From Table 3 (termites), the highest coliforms count was observed from L1 with $1.9775 \pm 0.08 \log _{10} \mathrm{CFU} / \mathrm{g}$ but were not detected on L3 and L5. Location L5 had no $E$. coli count while the highest count was obtained from L4 with $1.9907 \pm 0.05 \log _{10} \mathrm{CFU} / \mathrm{g}$. The Salmonella spp. varied from 0 to $1.9827 \pm 0.03 \log _{10} \mathrm{CFU} / \mathrm{g}$ whereas the highest count was on L1. S. aureus count was not detected on locations L1 to L3 while the highest count was observed on L4 at $2.2562 \pm 0.02 \log _{10} \mathrm{CFU} / \mathrm{g}$. Total plate counts ranged from $1.8773 \pm 0.04$ to $6.3564 \pm 1.10$ $\log _{10} \mathrm{CFU} / \mathrm{g}$. The highest total viable count (TVC) was obtained from L5 and lowest from L2. The yeast counts ranged $1.0624 \pm 0.07$ to $1.9098 \pm 0.02 \quad \log _{10} \mathrm{CFU} / \mathrm{g}$. The highest count was observed from L2 and the lowest count from L5. Therefore, TVC and yeast counts were available in all locations. Mould was not available on locations L1 and L2 while the highest count was obtained from L4 with $1.6981 \pm 0.30 \log _{10} \mathrm{CFU} / \mathrm{g}$.

\subsubsection{Microbial analysis of stink bugs}

Table 4 indicates the bacterial populations isolated from stink bugs. The highest coliform counts were obtained from location L4 with $1.9476 \pm 0.07 \log _{10} \mathrm{CFU} / \mathrm{g}$ while L3 had no count. E. coli counts varied from $1.6162 \pm 0.18$ to $1.8472 \pm 0.08 \log _{10}$ CFU/g. The highest count was observed from L5 and the lowest count on L1.

Table 2. Microbial analysis of mopane worms $\left(\log _{10} \mathrm{CFU} / \mathrm{g}\right)$

\begin{tabular}{cccccccc}
\hline Location & Coliforms & E. coli & Salmonella spp. & S. aureus & TVC & Yeasts & Moulds \\
\hline L1 & $1.2196 \pm 0.31^{\mathrm{b}}$ & $1.7071 \pm 0.02^{\mathrm{a}}$ & ND & ND & $1.7899 \pm 0.13^{\mathrm{c}}$ & $1.9681 \pm 0.01^{\mathrm{a}}$ & ND \\
L2 & $1.9964 \pm 0.02^{\mathrm{a}}$ & $1.6266 \pm 0.06^{\mathrm{b}}$ & $1.5896 \pm 0.10^{\mathrm{a}}$ & ND & $1.9422 \pm 0.02^{\mathrm{a}}$ & $1.9599 \pm 0.02^{\mathrm{a}}$ & ND \\
L3 & ND & ND & $1.5663 \pm 0.51^{\mathrm{a}}$ & ND & $1.8193 \pm 0.11^{\mathrm{b}}$ & $1.6972 \pm 0.04^{\mathrm{d}}$ & $1.1003 \pm 0.17^{\mathrm{b}}$ \\
L4 & ND & ND & ND & $1.7707 \pm 0.00^{\mathrm{a}}$ & $1.234 \pm 0.12^{\mathrm{e}}$ & $1.8673 \pm 0.15^{\mathrm{b}}$ & $1.2594 \pm 0.24^{\mathrm{a}}$ \\
L5 & ND & ND & ND & $1.7088 \pm 0.10^{\mathrm{b}}$ & $1.4103 \pm 0.19^{\mathrm{d}}$ & $1.7153 \pm 0.12^{\mathrm{c}}$ & $1.2006 \pm 0.17^{\mathrm{b}}$ \\
\hline
\end{tabular}

Values are expressed as mean \pm standard deviation, $\mathrm{n}=3$. Values followed by the same letters in the same column are significantly different $(\mathrm{p}<0.05) . \mathrm{L} 1-\mathrm{L} 5=$ locations. $\mathrm{ND}=$ not detected. 
Table 3. Microbial analysis of termites $\left(\log _{10} \mathrm{CFU} / \mathrm{g}\right)$

\begin{tabular}{cccccccc}
\hline Location & Coliforms & E. coli & Salmonella spp. $^{\mathrm{S}}$ S. aureus & TVC & Yeasts & Moulds \\
\hline L1 & $1.9775 \pm 0.08^{\mathrm{a}}$ & $1.0813 \pm 0.11^{\mathrm{c}}$ & $1.9827 \pm 0.03^{\mathrm{a}}$ & ND & $1.9940 \pm 0.08^{\mathrm{a}}$ & $1.7963 \pm 0.08^{\mathrm{b}}$ & ND \\
L2 & $1.7845 \pm 0.03^{\mathrm{b}}$ & $1.5444 \pm 0.06^{\mathrm{b}}$ & $1.6310 \pm 0.11^{\mathrm{b}}$ & ND & $1.8773 \pm 0.04^{\mathrm{c}}$ & $1.9098 \pm 0.02^{\mathrm{a}}$ & ND \\
L3 & ND & $1.9817 \pm 0.29^{\mathrm{a}}$ & ND & ND & $1.9004 \pm 0.03^{\mathrm{b}}$ & $1.6149 \pm 0.12^{\mathrm{c}}$ & $1.1003 \pm 0.17^{\mathrm{c}}$ \\
L4 & $1.1830 \pm 0.42^{\mathrm{c}}$ & $1.9907 \pm 0.05^{\mathrm{a}}$ & $1.5762 \pm 0.24^{\mathrm{c}}$ & $2.2562 \pm 0.02^{\mathrm{a}}$ & $1.9787 \pm 0.02^{\mathrm{a}}$ & $1.5926 \pm 0.11^{\mathrm{d}}$ & $1.6981 \pm 0.30^{\mathrm{a}}$ \\
L5 & ND & ND & $1.6830 \pm 0.14^{\mathrm{b}}$ & $1.9033 \pm 0.06^{\mathrm{b}}$ & $1.3564 \pm 1.10^{\mathrm{d}}$ & $1.0624 \pm 0.07^{\mathrm{e}}$ & $1.2006 \pm 0.17^{\mathrm{b}}$ \\
\hline
\end{tabular}

Values are expressed as mean \pm standard deviation, $\mathrm{n}=3$. Values followed by the same letters in the same column are significantly different $(\mathrm{p}<0.05)$. L1 $-\mathrm{L} 5=$ locations. ND $=$ not detected.

Table 4. Microbial analysis of stink bugs $\left(\log _{10} \mathrm{CFU} / \mathrm{g}\right)$

\begin{tabular}{cccccccc}
\hline Location & Coliforms & E. coli & Salmonella spp. & S. aureus & TVC & Yeasts & Moulds \\
\hline L1 & $1.8773 \pm 0.06^{\mathrm{c}}$ & $1.6190 \pm 0.12^{\mathrm{c}}$ & $1.9827 \pm 0.03^{\mathrm{a}}$ & ND & ND & $1.9804 \pm 0.14^{\mathrm{a}}$ & ND $^{\mathrm{a}}$ \\
L2 & $1.9078 \pm 0.02^{\mathrm{b}}$ & $1.2838 \pm 0.05^{\mathrm{d}}$ & $1.6310 \pm 0.11^{\mathrm{c}}$ & ND & $1.6622 \pm 0.02^{\mathrm{c}}$ & $1.8373 \pm 0.04^{\mathrm{b}}$ & $1.2006 \pm 0.17^{\mathrm{c}}$ \\
L3 & ND & $1.6162 \pm 0.18^{\mathrm{c}}$ & ND & ND & $1.8404 \pm 0.02^{\mathrm{b}}$ & $1.5257 \pm 0.18^{\mathrm{d}}$ & $1.9491 \pm 0.56^{\mathrm{a}}$ \\
L4 & $1.4928 \pm 0.13^{\mathrm{d}}$ & $1.7581 \pm 0.08^{\mathrm{b}}$ & $1.5762 \pm 0.24^{\mathrm{d}}$ & $1.9948 \pm 0.03^{\mathrm{a}}$ & $1.8075 \pm 0.03^{\mathrm{b}}$ & $1.7904 \pm 0.07^{\mathrm{c}}$ & $1.7669 \pm 0.20^{\mathrm{b}}$ \\
L5 & $1.9476 \pm 0.07^{\mathrm{a}}$ & $1.8472 \pm 0.08^{\mathrm{a}}$ & $1.6830 \pm 0.14^{\mathrm{b}}$ & $2.0136 \pm 0.02^{\mathrm{a}}$ & $1.9521 \pm 0.02^{\mathrm{a}}$ & $1.0988 \pm 0.06^{\mathrm{e}}$ & $1.2006 \pm 0.17^{\mathrm{c}}$ \\
\hline
\end{tabular}

Values are expressed as mean \pm standard deviation, $\mathrm{n}=3$. Values followed by the same letters in the same column are significantly different $(\mathrm{p}<0.05) . \mathrm{L} 1-\mathrm{L} 5=$ locations. ND $=$ not detected.

Salmonella spp. varied from 0 to $1.9827 \pm 0.03 \log _{10} \mathrm{CFU} /$ g. The highest count was observed from L1 while L3 had no count. $S$. aureus was not available on locations L1 to L3 whereas the highest count was obtained from L5 with $2.0136 \pm 0.02 \log _{10} \mathrm{CFU} / \mathrm{g}$. Location L1 had no TVC while the highest count was observed in L5 with $1.9521 \pm 0.02 \log _{10} \mathrm{CFU} / \mathrm{g}$. Yeast counts were isolated from all locations for stink bugs, however, the counts ranged from $1.0988 \pm 0.06$ to $1.9804 \pm 0.14 \log _{10} \mathrm{CFU} / \mathrm{g}$. The highest yeast count was observed from L1 and the lowest count from L5. The highest mould count was observed from L3 with $1.9491 \pm 0.56 \quad \log _{10} \mathrm{CFU} / \mathrm{g}$ whereas L1 had no count. Therefore, E. coli and yeast counts were available in all locations.

\section{Discussion}

\subsection{Food hygiene practice}

Personal hygiene is a very important measure that needs to be taken into consideration during food handling because humans are carriers and can cause food contamination (Mosupye and von Holy, 1999). The working garments or clothes should be always kept clean and hair should be covered with hair nets to avoid contaminating the insects (Birgen et al., 2020). However, this advice is often disregarded by street vendors. For example, Muindi and Kuri (2005) reported that in Kenya, $85 \%$ of the vendors prepared their food in unhygienic condition.

Traditionally, most of the bowls and weighing cups used for storing insects are not covered. Street vendors in this study also did not cover their utensils. Their reasoning is that if they cover their bowls or cups, customers would not see their products and this would reduce their sales. Therefore, keeping the food uncovered is viewed as a marketing strategy. Unfortunately, since the food is uncovered, during the dry windy season soil and dust settle in the storage containers. Moreover, insects are exposed to the sun and are stored in ambient temperature. There is no monitoring of temperature and these foodstuffs are often exposed for 6 to $8 \mathrm{hrs}$ a day. This poses a great risk to public health.

By contrast, Okojie and Isah (2014) found that 94\% of street vendors in Benin City, Nigeria, sold food from covered containers. In this study, some vendors put their bowl on the surface where the insects can be easily contaminated by microorganisms and small particles like small stone and unwanted materials. The number of street vendors with shelter was high as compared to report by Birgen et al. (2020) whereby 33\% of vendors had proper shelter. Similarly, Chukuezi (2010) in Owerri, Nigeria, also reported that only $29 \%$ of the vending sites had a canopy. Muinde and Kuria (2005) indicated that structures such as canopy and umbrella might not protect street foods from the smoke of vehicles as well as dust from the surrounding environment which carries many pathogenic microbes. This poses health hazards to consumers of foods sold in the street such as dried insects.

Lack of running water or potable water storage compromises food safety conditions for street vendors and consumers since water is required to wash hands, utensils and equipment (Omemu and Aderoju, 2008; Rane, 2011; Proietti et al., 2014). The unavailability of proper washing facilities at the sites makes vendors likely vectors of food contaminants. The observation of poor sanitary conditions where most street vendors operated is in contrast with the findings of Chukuezi 
(2010) in Owerri, Nigeria, and Mensah et al. (2002) in Accra, Ghana, whereby most of the street vendors had onsite water and waste bins. Foodborne diseases can be prevented by good hygiene practices such as the use of Hazard Analysis Critical Control Point (HACCP) application in the chain of food production, processing and storage. Educating or training food handlers/food vendors about food safety measures should be properly investigated by the private or public institutes in order to prevent foodborne diseases (Vandeweyer, 2018).

\subsection{Microbial analysis of dried insects}

Foodborne illnesses which are caused mainly by pathogenic bacteria found in contaminated foods are a major worldwide problem, especially in developing countries, causing death to vulnerable people. This is especially a problem where food standards, regulations, safety policies, cooling and storage facilities are not well established or not in place (Ntuli et al., 2017). In the current study, the highest coliforms of $1.9964 \pm 0.02 \log _{10}$ $\mathrm{CFU} / \mathrm{g}$ on L2 were found in mopane worms. Coliform counts of dried insects were within expected limits of less than $10^{3} \mathrm{CFU} / \mathrm{g}$ in foodstuffs that require further cooking or in cured and salted meat (Lim et al., 2012). Mujuru et al. (2014) reported mean ranges of $0-4.3$ $\mathrm{CFU} / \mathrm{g}$ of coliforms on edible dried insects. All the dried insects studied were safe for human consumption; however, coliforms have been used as an indicator of unsanitary conditions and quality in water and food products (Cornell University, 2007).

Although still within the specified limit on L4, termites had the highest $E$. coli of $1.9907 \pm 0.05 \log _{10}$ $\mathrm{CFU} / \mathrm{g}$ as compared to other dried insects such as mopane worms and stink bugs. These results are like those by Mujuru et al. (2014) who detected E. coli in dried insects ranging from 0.0 to $3.0 \log _{10} \mathrm{CFU} / \mathrm{g}$. Lim et al. (2012) also reported counts of less than $10^{3}$ for foodstuffs that require further cooking or in cured and salted meat. According to the current German and European community threshold, E. coli should range from 0 - 4.0 CFU/g (Grabowski and Klein, 2017). The presence of E.coli in food generally indicates direct or indirect faecal contamination. A substantial number of E.coli in foods suggests a general lack of cleanliness in handling and improper storage (Centre for Food Safety, 2014).

Salmonella species had the highest similar count on termites and stink bugs of $1.9827 \pm 0.03 \log _{10} \mathrm{CFU} / \mathrm{g}$ as compared to mopane worms (L4). Although it was very low, Klunder et al. (2012) also detected Salmonella from edible insects. Vandeweyer et al. (2018) reported that the specification of Salmonella spp. on dried insects is $<100$ $\mathrm{CFU} / \mathrm{g}$. The results of this study indicate that the edible insects are safe for human consumption even though the container carrying the insects were not covered and there is a high risk of contamination by unwanted materials. Food may be contaminated by Salmonella spp. in animal faeces and cross-contamination may occur during further processing and preparation (Centre for food safety, 2014).

Termites had the highest count on $S$. aureus of $2.2562 \pm 0.02 \log _{10} \mathrm{CFU} / \mathrm{g}$ as compared to mopane worms and stink bugs on L4. In a study conducted by Grabowski et al. (2016), S. aureus in boiled and dried insects ranged between 2.000 to $6.327 \log _{10} \mathrm{CFU} / \mathrm{g}$. Although $S$. aureus was present on mopane worms, termites and stink bug, they were within the expected limits of less than $10^{3} \mathrm{CFU} / \mathrm{g}$ in foodstuffs that require further cooking or in cured and salted meat (Mujuru et al., 2014). Vandeweyer et al. (2018) reported that the specification of $S$. aureus on dried insects is $<100 \mathrm{CFU} /$ g. S. aureus is a bacterium that causes Staphylococcal food poisoning, a form of gastroenteritis with rapid onset of symptoms (Stewart, 2003). The results revealed that contamination could be caused by poor handling from harvesting to storage. Food handlers are the main source of food contamination through direct contact and it can occur via hands or respiratory secretions (Food Standards Australia New Zealand, 2016).

Total viable count (TVC) is one of the key indicators of poor hygiene afforded when processing food. Termites had the highest TVC of $6.3564 \pm 1.10 \log _{10}$ $\mathrm{CFU} / \mathrm{g}$ on L5. TVC is an acceptable measure of the general degree of bacterial contamination in processing plants (Cohen et al., 2007). Mpuchane et al. (2010) recorded TVC of approximately $4.0-8.0 \log _{10} \mathrm{CFU} / \mathrm{g}$ in dried insects. Campos et al. (2008) reported TVC in the range of $4.0-5.1 \log _{10} \mathrm{CFU} / \mathrm{g}$ in dried insects. The International Commission of Microbiological Specification for Foods (1986); Vandeweyer et al. (2018) reported that the microbial limit of TVC should be less than $7 \log _{10} \mathrm{CFU} / \mathrm{g}$. Therefore, the results of TVC of mopane worms, termites and stink bugs were within this acceptable range and hence safe to consume.

Yeast and moulds may cause food spoilage in food products that have low water activity such as dried edible insects. The ability of yeasts and moulds to attack many foods is due to their relatively versatile environmental requirements (Tournas et al., 2001). Stink bugs had the highest yeast and mould counts of $1.9804 \pm 0.14$ and $1.9491 \pm 0.56 \log _{10} \mathrm{CFU} / \mathrm{g}$ as compared to other insects on L1 and L3. Yeasts and moulds were found in these dried insects although in low levels. The microbial limits of yeast and mould counts are $5 \log _{10} \mathrm{CFU} / \mathrm{g}$ on dried insects (Vandeweyer et al., 2018). In another study, 
smoked termites were found to be containing about $\log _{10}$ $5.62 \mathrm{CFU} / \mathrm{g}$ of yeast and moulds while those subjected to blanching were $<1.0 \log _{10} \mathrm{CFU} / \mathrm{g}$ (Megido et al., 2017). Their presence could be attributed to dust and air (Frazier and Westhoff, 2007).

According to the current German and European community threshold, yeast should be in the range of 1.0 - 3.0 CFU/g (Grabowski and Klein, 2017). Therefore, the findings of the current study are within the acceptable range. Microbial loads of all dried insects studied were within the specification and this might be due to the drying process which reduces the risk of microbial growth and contamination. Some of the insects are seasoned with salts which also improve quality and increases storage stability. However, the moisture content and water activity of dried insects is below $10 \%$ and 0.60 . They can be stored at an ambient temperature and be eaten at any time (Vandeweyer et al., (2018).

\section{Conclusion}

This study leads to the conclusion that dried mopane worms, termites and stink bug sold around Thohoyandou market had low levels of coliforms, E. coli, S. aureus, Salmonella spp., TPC, yeasts and moulds. All these contaminants were found to be within health and food specifications. Even though the levels of these microbial counts were low, their occurrence is still worrying because they could be attributed to the unhygienic manner street vendors store their products. The products are stored in open containers at the market which exposes food to adverse environmental factors.

\section{Conflict of interest}

The authors have no potential conflict of interest.

\section{Acknowledgements}

Authors would like to thank the Department of Food Science and Technology, University of Venda for funding the project.

\section{References}

Ahmed, T., Sharmin, A., Paul, A., Dipu, M.R. and Islam, T. (2020). Microbiological quality analysis of different types of popular dried food items. Food Research, 4(4), 1297 - 1302. https:// doi.org/10.26656/fr.2017.4(4).080.

Amadi, E.N. and Kiin-Kabari, D.B. (2016). Nutritional composition and microbiology of some edible insects commonly eaten in Africa, Hurdles and future prospects: A critical review. Journal of Food: Microbiology, Safety and Hygiene, 1(1), 1-7. https:// doi.org/10.4172/2476-2059.1000107.

Birgen, B.J., Njue, L.G., Kaindi, D.M., Ogutu, F.O. and Owade. J.O. (2020). Determinants of microbial contamination of street-vended chicken products sold in Nairobi County, Kenya. International Journal of Food Science, 2020, 2746492. https:// doi.org/10.1155/2020/2746492.

Bourdoux, S., Li, D., Rajkovic, A., Devlieghere, F. and Uyttendaele, M. (2016). Performance of drying technologies to ensure microbial safety of dried fruits and vegetables. Comprehensive Reviews in Food Science and Food Safety, 15(6), 1056-1066. https://doi.org/10.1111/1541-4337.12224.

Campos, M.G.R., Bogdanov, S., Bicudo, A.M., Szczesna, T., Mancebo, Y., Frigerio, C. and Ferreira, F. (2008). Pollen composition and standardisation of analytical methods. Journal of Agricultural Research, 47(2), 154-161. https://doi.org/10 10.3896/IBRA.1.47.2.12.

Centre for Food Safety, Food and Environmental Hygiene Department. (2014). Microbiological guidelines for food. For ready-to-eat food in general and specific food items. Retrieved on April 24, 2020 from Website: https://www.cfs.gov.hk/english/ food leg/files/

food_leg_Microbiological_Guidelines_for_Food_e.p $\mathrm{df}$

Chukuezi, C.O. (2010). Food safety knowledge and practices of street food vendors in Owerri, Nigeria. Studies in Sociology of Science, 1(1), 50-57. https:// doi.org/1010.4236/odem.2017.51002.

Cloutier, J. (2015). Edible Insects in Africa: An Introduction to finding, using and eating insects. 1st ed. Wageningen Digigrafi, Veenendaal, Netherland: Agromisa Foundation and CTA. https:// doi.org/10.3920/JIFF2015.x005a

Cornell University. (2007). Coliform Bacteria. Indicators in food and water. Dairy Foods Science Notes, 1-2. Retrieved on April 20, 2020 from Cornell University Website: https://foodsafety.foodscience.cornell.edu/ sites/foodsafety.foodscience.cornell.edu/files/shared/ documents/CU-DFScience-Notes-Bacteria-Coliform -Indicators-09-07.pdf.

Schluter, O., Rumpold, B., Holzhauser, T., Roth, A., Vogel, R.F., Quasigroch, W., Vogel, S., Heinz, V., Jager, H., Bandick, N., Kulling, S., Knorr, D., Steinberg, P. and Engel, K.H. (2017). Safety aspects of the production of foods and food ingredients from insects. Molecular Nutrition and Food Research, 61 (6), $\quad 1600520 . \quad$ https://doi.org/10.1002/ mnfr. 201600520

Farahbakhsh, E., Pakbin, B., Mahmoudi, R., Katiraee, F., 
Kohannia, N. and Valizad, S. (2015). Microbiological quality of raisin dried by different methods. International Journal of Food Nutrition and Safety, 6(2), 62-66.

Figueiredo, R.E., Vasconceilos, A., Pollicarpo, L.S. and Alves, R.R. (2015). Edible and medicinal termites: a global review. Journal of Ethnobiology and Ethnomedicine, 11(29), 1-7. https://doi.org/10.1186/ s13002-015-0016-4.

Food Standards Australia New Zealand. (2016). Retrieved on March 20, 2020 from Food Standards Australia New Zealand Website: www.foodstandards.gov.au.

Frazier, N.F. and Westhoff, P.C. (2007). Food Microbiology, $3^{\text {rd }}$ ed., p. 454-456. India: Tata Mc Graw-Hill Publishing co. India.

Grabowski, N.T. and Klein, G. (2016). Microbiology of cooked and dried edible Mediterranean field crickets (Gryllus bimaculutus) and super worms (Zopho basatratus) submitted to four different heating treatments. Food Science and Technology International, 23(1), 17-23. https:// doi.org/10.1177/1082013216652994.

Grabowski, N.T. and Klein, G. (2017). Microbiology of processed edible insect products - Results of a preliminary survey. International Journal of Food Microbiology, 243, 103-107. https://doi.org/10.1016/ j.ijfoodmicro.2016.11.005.

Hamerman, E.J. (2016). Cooking and disgust sensitivity influence preference for attending insect-based food events. Appetite, 96, 319-326. https:// doi.org/10.1016/j.appet.2015.09.029.

International Commission for Microbiological Specification of Food. (1986). Microorganisms in foods 2. Sampling for microbial analysis: Principles application. Australia: ICMSF Blackwell Scientific Publications.

Jeong-Eun, H., Ji-Yeon, K., Eun-Mi, K., Jong-Chan, K. and Sun-Young, L. (2019). Changes in microbiological and physicochemical quality of dried persimmons (Diospyros kaki Thunb.) stored at various temperatures. Journal of Food Quality, 2019, 625640. https://doi.org/10.1155/2019/6256409.

Kooh, P., Ververis, E., Tesson, V., Boué, G. and Federighi, M. (2019). Entomophagy and public health: A review of microbiological hazards. Health, 11, 1272-1290. https://doi.org/10.4236/ health.2019.1110098.

Kouřimská, L. and Adámková, A. (2016). Nutritional and sensory quality of edible insects. NFS Journal, 4, 22-26. http://dx.doi.org/10.1016/ j.nfs.2016.07.001.
Klunder, H.C., Workers, R.J., Korpela, J.M. and Nout, M.J.R. (2012). Microbiological aspects of processing and storage of edible insects. Food Control, 26(2), 628-631. https://doi.org/10.1016/ j.foodcont.2012.02012.

Lim, E.L., Lopez, A., Cressey, B.P. and Pirie, R. (2012). Annual report concerning foodborne diseases in New Zealand. New Zealand: Ministry for Primary Industry.

Mafune, T.S., Takalani, T.K., Anyasi, T.A. and Ramashia, S.E. (2016). Microbial safety of street vended foods sold in Thohoyandou, South Africa. Journal of Human Ecology, 53(3), 205-212. https:// doi.org/10.1080/09709274.2016.11906973.

Megido, R.C., Desmede, S., Blecker, C., Bera, F., Haabruge, E., Alabi, T. and Francis, F. (2017). Microbiological load of edible insects found in Belgium. Insects, 8(12), 1-8. https://doi.org/10.3390/ insects8010012.

Mensah, P, Yeboah-Manu, D., Owusu-Darko, K. and Ablordey, A. (2002). Street foods in Accra, Ghana: how safe are they?" Bulletin of the World Health Organization, 80(7), 546- 554.

Messina, C.M., Gaglio, R., Morghese, M., Tolone, M., Arena, R., Moschetti, G., Santulli, A., Francesca, N. and Settanni, L. (2019). Microbiological profile and bioactive properties of insect powders used in food and feed formulations. Foods, 8(4), 1-16. https:// doi.org/10.3390/foods8090400.

Milanovic, V., Osimani, A., Pasquini, M., Aquilanti, L., Garofalo, C., Taccari, M. and Clementi, F. (2016). Getting insight into the prevalence of antibiotic resistance genes in specimens of marketed edible insects. International Journal of Food Microbiology, 227, 22-28. https://doi.org/10.1016/ j.ijfoodmicro.2016.03.018.

Mosupye, F.M. and von Holy, A. (1999). Microbiological quality and safety of ready-to-eat street vended foods in Johannesburg, South Africa. Journal of Food Protection, 62(11), 1278-1284. https://doi.org/10.4315/0362-028X-62.11.1278.

Mpuchane, S., Gashe, B.A., Allotey, J., Siame, B., Teferra, G. and Dithogo, M. (2000). Quality deterioration of phane, the edible catepillar of an emperor moth Imbra siabelina. Food control, 11, 453-458. https://doi.org/10.1016/S0956-7135(00) 00010-4.

Muinde, K.O. and Kuria, E. (2015). Hygienic and sanitary practices of vendors of street foods. African Journal of Food, Agriculture, Nutrition and Development, 5(1), 1-15.

Mujuru, F.M., Kwiri, R., Nyambi, C., Winini, C. and 
Moyo, D.N. (2014). Microbiological quality of Gonim brasiabelina processed under different traditional practices in Gwanda, Zimbabwe. International Journal of Current Microbiology and Applied Science, 3(9), 1085-1094.

Musundire, R., Osuga, I.M., Cheseto, K., Irungu, J. and Torto, B. (2016). Aflatoxin contamination detected in nutrient and anti-nutrient oxidant rich edible Stink bug stored in recycled grain containers. PLOS ONE, 11(1): e0145914, https://doi.org/10.1371/ journal.pone. 0145914

Ntuli, V., Chatanga, P., Kwiri, R., Gadaga, H., Tendekayi, G.J., Matsepo, T. and Potloane, R.P. (2017). Microbiological quality of selected dried fruits and vegetables in Maseru, Lesotho. African Journal of Microbiology Research, 11(5), 185-193. https://doi.org/10.5897/AJMR2016.8130.

Okojie, P.W. and Isah, E.C. (2014). Sanitary conditions of food vending sites and food handling practices of street food vendors in Benin City, Nigeria: Implication for food hygiene and safety. Journal of Environmental and Public Health, 2014, 701316, http://dx.doi.org/10.1155/2014/701316.

Omemu, A.M., Okafor, U.I., Obadina, A.O., Mobolaji, O., Bankole, M.O. and Adeyeye, S.A.O. (2018), Microbiological assessment of maize ogi cofermented with pigeon pea. Food Science and Nutrition, 6(5), 1238-1253. https://doi.org//10.1002/ fsn3.651.

Omemu, A.M. and Aderoju, S.T. (2008). Food safety knowledge and practices of street food vendors in the city of Abeokuta, Nigeria. Food Control, 19(4), 396-402.

https://doi.org/10.1016/ j.foodcont.2007.04.021.

Oppong, B.B. (2013). Mopane worms and household food security in Limpopo Province, South Africa. Agricultural Economics. Pietermaritzburg, South Africa: University of KwaZulu-Natal, MSc. Thesis.

Osimani, A., Garofalo, C., Milanovic', V., Taccari, M., Cardinali, F., Aquilanti, L., Pasquini, M., Mozzon, M., Raffaelli, N., Ruschioni, S., Riolo, P., Isidoro, N. and Clementi, F. (2016). Insight into the proximate composition and microbial diversity of edible insects marketed in the European Union. European Food Research and Technology, 243, 1157-1171. https:// doi.org/10.1007/s00217-016-2828-4.

Pal, S. and Karmakar, P. (2018). Symbionts associated with insect digestive system and their role in insect nutrition. Journal of Entomology and Zoology Studies, 6(5), 421-425.

Park, R., Dzialo, M.C., Spaepen, S., Nsabimana, D., Gielens, K., Devriese, H., Crauwels, S., Tito, R.Y.,
Raes, J., Lievens, B. and Verstrepen, K.J. (2019). Microbial communities of the house fly Musca domestica vary with geographical location and habitat. Microbiome, 7(147), 1-12. https:// doi.org/10.1186/s40168-019-0748-9.

Proietti, I., Frazzoli, C. and Mantovani, A. (2014). Identification and management of toxicological hazards of street foods in developing countries. Food and Chemical Toxicology, 63, 143-152. https:// doi.org/10.1016/j.fct.2013.10.047.

Rane, S. (2011). Street vended food in developing world: hazard analyses. Indian Journal of Medical Microbiology, 51(1), 100-106. https:// doi.org/10.1007/s12088-011-0154-x.

Raphael, K., Clive, W., Perkins, M.J., Jeritah, T., Wishmore, G., Felix, M. and Shannon, T. G. (2014). Mopane worm utilisation, a potential source of protein in fortified blended foods in Zimbabwe. A review. Global Journal of Science Frontier Research: D Agriculture and Veterinary, 14(10), 5567.

Samapundo, S., Climat, R., Xhaferi, R. and Devlieghere, F. (2015). Food safety knowledge, attitudes and practices of street food vendors and consumers in Port-au-Prince, Haiti. Food Control, 50, 457-466. https://doi.org/10.1016/j.foodcont.2014.09.010

Stewart, C.M. (2003). Staphylococcus aureus and Staphylococcal enterotoxins. Foodborne microorganisms of public health significance, presented at Australian Institute of Food Science and Technology (NSW Branch), Sydney, 2014.

Terentjeva, M., Avsejenko, J., Streikisa, M. Utinane, A., Kovalenko, K. and Berzins, A. (2017). Prevalence and antimicrobial resistance of Salmonella in meat and meat products in Latvia. Annals Agricultural and Environmental Medicine, 24, 317-321. https:// doi.org/10.5604/12321966.1235180.

Tope, A.K. (2014). Microbial analysis of sun-dried okra samples from some Akoko areas of Ondo state, Nigeria. International Journal of Research in Applied, Natural and Social Sciences, 2(5), 87-96.

Tournas, V., Stack, M.E., Mislivec, P.B., Koch, H.A. and Bandler, R. (2001). BAM: Yeasts, Molds and Mycotoxins. Retrieved from FDA BAM website: https://www.fda.gov/food/laboratory-methods-food/ bam-chapter-18-yeasts-molds-and-mycotoxins

van der Fels-Klerx, H.J., Camenzuli, L., Belluco, S., Meijer, N. and Ricci, A. (2018). Food safety issues related to uses of insects for feeds and foods. Comprehensive Reviews in Food Science and Safety, 17(5), 1172-1183. https://doi.org/10.1111/15414337.12385 . 
van Huis, A. (2013). Potential of insects as food and feed in assuring food security. Annual Revision of Entomology, 58, 563-583. https://doi.org/10.1146/ annurev-ento-120811-153704.

Vandeweyer, D., Wynants, E., Crauwels, S., Verreth, C., Viaene, N., Claes, J., Lievens, B. and Van Campenhout, L. (2018). Microbial dynamics during industrial rearing, processing and storage of tropical house crickets (Gryllodes sigillatus) for human consumption. Applied Environmental Microbiology, 84(12), e00255-18. http://doi.org/10.1128/ AEM.00255-18.

Vandeweyer, D. (2018). Microbiological quality of raw edible insects and impact of processing and preservation. Leuven: KU Leuven University. PhD Thesis. 